\title{
Sapling Survival and Growth in a Restoration Project of a Drained Wetland Forest in Southeastern Brazil
}

\author{
Odirlei Simões Oliveira ${ }^{1}$ \\ Nathalle Cristine Alencar Fagundes ${ }^{2,3}$ \\ Maria das Dores Magalhães Veloso 4 (1)
}

\begin{abstract}
The aim of this research was to evaluate the survival and growth of native tree saplings planted in a drained Mauritia flexuosa palm swamp (vereda) in southeastern Brazil, and to identify suitable species for restoration projects in these hygrophilous environments. Total sapling survival at one-year post-planting was $48 \%$. The species with highest sapling survival and growth were Croton urucurana, Cecropia pachystachya, Erythroxylum citrifolium, Hirtella gracilipes and Tapirira guianensis. Lowest survival and growth were found in Mauritia flexuosa, Piper aduncum, Calophyllum brasiliense, Calyptranthes brasiliensis, Myrsine umbellata, Ladenbergia cujabensis and Ficus sp. We indicate the high-survival species for the restoration of these environments. Typical wetland species attained low survival and growth, indicating the negative influence of anthropization on this ecosystem's resilience, and highlighting the importance of studies investigating suitable strategies to restore them.
\end{abstract}

Keywords: Croton urucurana, Cecropia pachystachya, Erythroxylum citrifolium, Hirtella gracilipes, Tapirira guianensis.

\section{INTRODUCTION}

Mauritia flexuosa palm swamps (known as veredas in Brazil) are wetlands established in partially or permanently flooded hydromorphic or peat soils in areas of groundwater discharge (Ávila et al., 2016; Fagundes and Ferreira, 2016). Veredas communities are composed of two vegetation types: an herbaceous-graminoid layer that covers most of its area, and a shrub-tree layer with a predominance of the palm Mauritia flexuosa L.f. (buriti) (Fagundes, 2014; Resende et al., 2013; Ávila et al., 2016). What distinguishes the veredas from other wetlands in Brazil (Fagundes and Ferreira, 2016) and characterizes them as structured hygrophilous forests is the presence of a dense arboreal layer bordering the areas of water table discharge (Bahia et al., 2009; Ávila et al., 2016). The protection of these ecosystems and maintenance of downstream watercourses depends on the maintenance of the veredas' water-soil and vegetation systems (Maruyama et al. 2013; Moreira et al. 2015).

The typically hydromorphic and water-saturated vereda soils directly influence plant community composition and distribution in these environments (Ávila et al., 2016; Fagundes and Ferreira, 2016). This constant presence of water confers floristic specificity to vereda sites, where only adapted species are able to successfully establishment (Fagundes, 2014). These species present morphological and anatomical adaptations that allow them to colonize flooded environments, causing an interdependence between species and flooding (LebrijaTrejos et al., 2010; Kurtz et al., 2013). Therefore, because flood-adapted species require wetter soils to establish, water deficit may hamper their survival or slow down their growth (Caspersen and Kobe, 2001).

Mauritia flexuosa palm swamps or veredas are poorly resilient and highly sensitive environments to anthropization

${ }^{1}$ Universidade Estadual de Montes Claros, Montes Claros, MG, Brasil

${ }^{2}$ Universidade do Estado de Minas Gerais, Ciências Biológicas, Ituiutaba, MG, Brasil

${ }^{3}$ Universidade Federal de Lavras, Departamento de Biologia, Lavras, MG, Brasil

${ }^{4}$ Universidade Estadual de Montes Claros, Biologia Geral, Montes Claros, MG, Brasil 
(Bahia et al., 2009). Anthropogenic activities, such as vegetation suppression, intensive cattle grazing, burning and artificial drainage, are common in these environments, mainly due to agricultural interests targeting their highly fertile soils (Azevedo et al., 2009; Fagundes and Ferreira, 2016). These impacts may trigger advanced environmental degradation processes, influencing the plant communities and altering associated watercourses (Ávila et al., 2016). These humaninduced alterations may lead to water deficit and preclude the colonization and establishment of flood-adapted species in these environments (Bahia et al., 2009; Fagundes, 2014). In these cases, environmental restoration initiatives may be needed to restore the regeneration capacity and ecosystem services provided by these areas.

The selection of suitable plant species to set off the succession process in degraded areas is one of the main determinants of a successful restoration (Neri et al., 2011). Due to great oscillation in plant survival rates, studies have called for the need to carefully select candidate species for restoration (Fagundes, 2014; Sabonaro et al., 2015). According to Sabonaro et al. (2015), planting and monitoring native tree saplings through periodic measurements are important steps toward successful restoration, for generating useful information to guide future projects. Thus, the objective of this research was to evaluate sapling survival and growth of native species planted in a drained Mauritia flexuosa palm swamp in southeastern Brazil, and determine which species are most suitable for restoration projects in these hygrophilous environments.

\section{MATERIALS AND METHODS}

\subsection{Study area}

Our study area was a Mauritia flexuosa palm swamp (vereda) located in a private reserve inserted in the Environmental Protection Area (APA) of the Pandeiros river, in the municipality of Januária, Minas Gerais state, Brazil. This region composes a dry sub-humid area susceptible to desertification, and is characterized as an ecotonal transition between three domains: Caatinga (an exclusively Brazilian domain, mostly composed by Seasonally Dry Tropical Forests; according Pennington et al., 2009), Cerrado (Brazilian Savannas) and Atlantic Forest. Species from these three domains compose the peculiar flora of the region and eventually cooccur locally (Rizzini, 1997; Azevedo et al., 2014). The region's climate type is Aw, with well-defined dry and rainy seasons (Alvares et al., 2014). Average annual temperature ranges from 21 to $24^{\circ} \mathrm{C}$; altitude ranges from 485 to $515 \mathrm{~m}$; and average rainfall varies from 900 to $1200 \mathrm{~mm}$ /year, mostly concentrated between November and January (INMET, 2014). However, the year when we planted the saplings, 2014, was atypically dry, with total annual rainfall of $394 \mathrm{~mm}$ (INMET, 2014) (Figure 1). In this figure, we see that rainfall in 2013 are bigger than in 2014, mainly in the first months. The next year of planting, 2015, are a year of low rainfall and high temperatures (Figure 1).

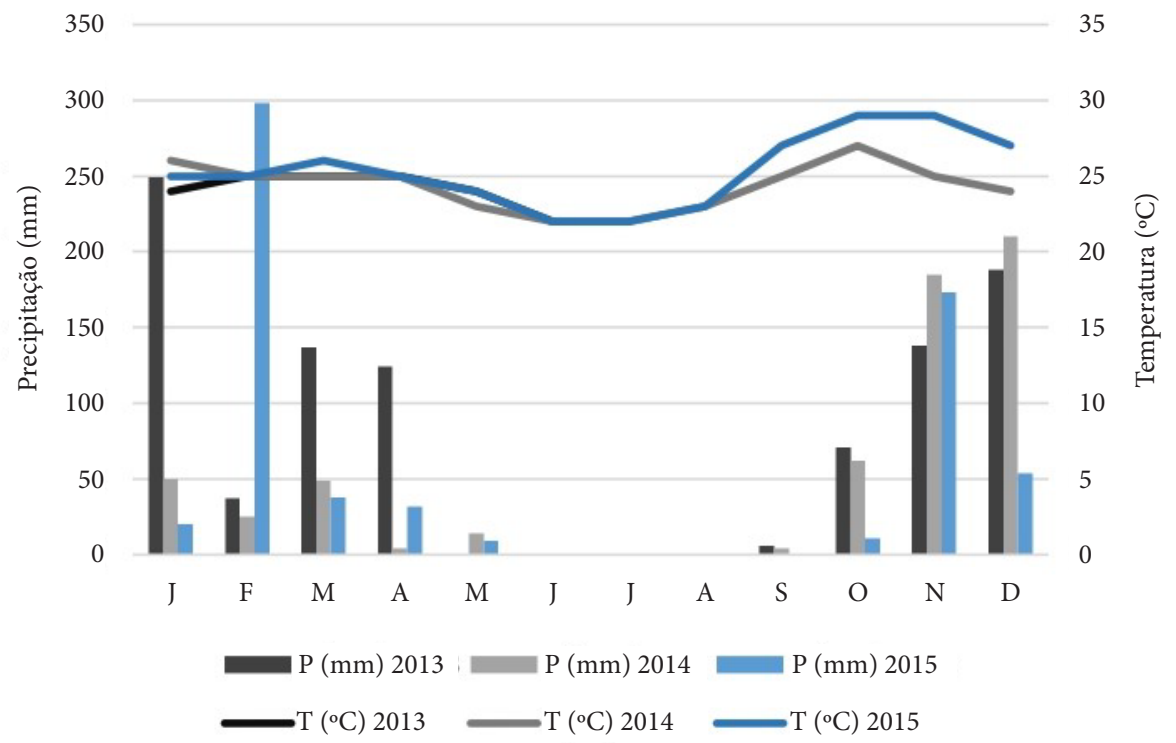

Figure 1. Mean monthly precipitation and temperature in the study area from 2013 to 2015. 
The study area is a Private Natural Heritage Reserve (Reserva Particular do Patrimônio Natural - RPPN in Portuguese). Before the status of a nature reserve, the area was subject to several anthropogenic activities, especially with the implementation of the Pró-Várzea governmental program in 1980. This program aimed to fund the cultivation of agricultural crops in several wetlands, including the veredas. With this incentive, during six years the study area underwent deforestation and soil drainage to give way to rice crops. After the crops were abandoned, the drainage lines remained open and native grasses occupied the site, which began to serve as cattle pasture. During the rainfall season, the area remains waterlogged for only a short period. In the remaining months, fire occurrence is frequent and contributes to advance the disturbed, or even degraded, state of the area. Up until we started to plant the saplings, sparse mature individuals of Mauritia flexuosa and some regenerating individuals of Melastomataceae, Cecropia pachystachya Trécul and Byrsonima sp occupied the area.

\subsection{Experimental design}

We established ten plots of $50 \mathrm{~m} \times 50 \mathrm{~m}$ (total area 2,500 $\mathrm{m}^{2}$ ) at the center of the Mauritia flexuosa palm swamp bordering the main drainage line. The whole area was fenced to avoid cattle trampling, one of the drivers of disturbance in the site. We removed shrubs and grasses from the planting rows before opening the pits where we would later plant the saplings. We distributed the planting rows $2 \mathrm{~m}$ apart from each other and parallel to the main drainage line. Along each row, the saplings were planted either $2 \mathrm{~m}$ or $3 \mathrm{~m}$ apart: in five plots, they were distanced by $2 \mathrm{~m}$, and in five other plots, by $3 \mathrm{~m}$. In June 2014, we planted a total 3737 saplings belonging to 15 genera and families (refer to Table 1 for species identities, guilds and individual numbers). We monitored sapling survival and growth after every fourmonth interval for the following 12 months post-planting (i.e., after 4,8 and 12 months). We used a steel ruler, graduated in centimeters and millimeters and a digital caliper to assess the growth variables, respectively: height and diameter at ground level. Species selection considerate phytosociological and other studies carried out in veredas in the region (Fagundes 2014; Ávila et al., 2016).
Table 1. Species, families, guilds and number (N) of saplings of the species planted in the environmental restoration of a vereda (Mauritia flexuosa palm swamps) in southeastern Brazil.

\begin{tabular}{|c|c|c|c|}
\hline Species & Family & Guild & $\mathbf{N}$ \\
\hline $\begin{array}{l}\text { Calophyllum brasiliense } \\
\text { Camb. }\end{array}$ & Clusiaceae & $\begin{array}{c}\text { Late } \\
\text { secondary }\end{array}$ & 27 \\
\hline $\begin{array}{l}\text { Calyptranthes } \\
\text { brasiliensis Spreng. }\end{array}$ & Myrtaceae & $\begin{array}{c}\text { Late } \\
\text { secondary }{ }^{4}\end{array}$ & 769 \\
\hline $\begin{array}{l}\text { Cecropia pachystachya } \\
\text { Trécul }\end{array}$ & Cecropiaceae & Pionner $^{3}$ & 191 \\
\hline $\begin{array}{l}\text { Croton urucurana } \\
\text { Bailon }\end{array}$ & Euphorbiaceae & Pionner $^{3}$ & 15 \\
\hline $\begin{array}{l}\text { Erythroxylum } \\
\text { citrifolium A.St-Hil. }\end{array}$ & Erythroxylaceae & Pionner ${ }^{1}$ & 15 \\
\hline Ficus sp. & Moraceae & $\begin{array}{l}\text { Late } \\
\text { secondary }\end{array}$ & 146 \\
\hline $\begin{array}{l}\text { Hirtella gracilipes } \\
\text { (Hook.f.) Prance }\end{array}$ & Chrisobalanaceae & $\begin{array}{c}\text { Early } \\
\text { secondary }^{3 / 5}\end{array}$ & 27 \\
\hline Inga vera Willd & Fabaceae & $\begin{array}{c}\text { Early } \\
\text { secondary }\end{array}$ & 337 \\
\hline $\begin{array}{l}\text { Ladenbergia cujabensis } \\
\text { Klotzsch }\end{array}$ & Rubiaceae & $\begin{array}{l}\text { Late } \\
\text { secondary }\end{array}$ & 60 \\
\hline Mauritia flexuosa L.f & Arecaceae & Pioneer & 775 \\
\hline Myrsine umbellata Mart & Primulaceae & $\begin{array}{c}\text { Early } \\
\text { secondary }\end{array}$ & 389 \\
\hline $\begin{array}{l}\text { Nectandra } \\
\text { megapotamica(Spreng.) } \\
\text { Mez }\end{array}$ & Lauraceae & $\begin{array}{c}\text { Early } \\
\text { secondary }{ }^{1}\end{array}$ & 325 \\
\hline $\begin{array}{l}\text { Ocotea aciphyla } \\
\text { (Nees\& Mart.) Mez }\end{array}$ & Lauraceae & $\begin{array}{l}\text { Late } \\
\text { secondary }{ }^{1}\end{array}$ & 44 \\
\hline Piper aduncumL. & Piperaceae & Herbaceous & 203 \\
\hline $\begin{array}{l}\text { Tapirira guianenses } \\
\text { Aubi }\end{array}$ & Anacardiaceae & Pionner ${ }^{4}$ & 414 \\
\hline
\end{tabular}

\subsection{Data analysis}

For each species, we obtained the percentage of total sapling survival (i.e., the percentage of surviving saplings compared with the initial number of saplings planted) and percentage of sapling survival across three assessment periods (4-, 8- and 12-months post-planting). To assess total sapling survival variation, we performed a one-way analysis of variance (one-way ANOVA), with the study's timeframe (12 months) as a predictor variable, and percentage of total sapling survival as a dependent variable. Survival and growth are the parameters used to or not recommend a species for restoration in veredas. To assess 
sapling survival variation across the three intervals (4-, 8and 12-months post-planting), we performed a factorial analysis of variance (factorial ANOVA), with the species and assessment months (4,8 and 12 months) as predictor variables, and percentage of sapling survival in-between them as dependent variables. To characterize and assess growth, we compared variations in height and diameter among species through a one-way ANOVA, with species as the predictor variable and growth (either diameter or height) as the dependent variable. All analyses of variance were performed according to a Generalized Linear Model (GLM) procedure followed by a Tukey's post hoc test in the software Statistic 10.0 (Zar 1996).

\section{RESULTS}

The percentage of total sapling survival was $48 \%$, but displayed significant variation within the 12 months of the study $(\mathrm{df}=2, \mathrm{~F}=5.01, \mathrm{p}<0.05)$, with a decreasing trend throughout the year (Table 2). Among the assessed species, survival varied significantly at the 4 -month assessment ( $\mathrm{df}=14, \mathrm{~F}=5.72, \mathrm{p}<0.05)$, at the 8 -month assessment $(\mathrm{df}=14, \mathrm{~F}=7.91, \mathrm{p}<0.05)$ and at 12 -month assessment $(\mathrm{df}=14, \mathrm{~F}=7.51, \mathrm{p}<0.05)$. The species with highest sapling survival were Croton urucurana, Cecropia pachystachya,
Erythroxylum citrifolium and Hirtella gracilipes (85, 77, 75 and $74 \%$, respectively). The species with lowest sapling survival were Calyptranthes brasiliensis, Piper aduncum, Calophyllum brasiliense and Mauritia flexuosa (21, 14, 8 and $6 \%$, respectively).

Diameter growth also varied significantly among species ( $\mathrm{df}=14, \mathrm{~F}=11.82, \mathrm{p}<0.05)$. The species with highest average diameter growth were Tapirira guianensis (4.72 \pm $0.29 \mathrm{~mm})$, Cecropia pachystachya $(3.41 \pm 0.48 \mathrm{~mm})$ and Croton urucurana $(3.16 \pm 0.95 \mathrm{~mm})$. The ones with lowest average diameter growth were Myrsine umbellata $(0.40 \pm$ $0.30 \mathrm{~mm})$, Ficus sp. $(0.89 \pm 0.62 \mathrm{~mm})$, Ladenbergia cujabensis $(-0.51 \pm 0.83 \mathrm{~mm})$ and Mauritia flexuosa $(-1.53 \pm 0.82 \mathrm{~mm})$. The latter two species showed a reduction in diameter after one year post-planting (Figure 2).

Height growth also varied significantly among species ( $\mathrm{df}=14, \mathrm{~F}=17,22, \mathrm{p}<0,05)$, with the highest averages found in Tapirira guianensis $(35.85 \pm 1.76 \mathrm{~cm})$, Hirtella gracilipes $(33.73 \pm 5.21 \mathrm{~cm})$, Cecropia pachystachya $(28.65 \pm 2.80 \mathrm{~cm})$ and Calophyllum brasiliense $(26.06 \pm 5.20 \mathrm{~cm})$. The lowest height growth averages were found in Myrsine umbellata $(4.05 \pm 2.89 \mathrm{~cm})$, Ladenbergia cujabensis $(2.80 \pm 3.42 \mathrm{~cm})$, Ficus sp. $(1.41 \pm 2.89 \mathrm{~cm})$, with the decrease in Piper aduncum $(-2.19 \pm 3.82 \mathrm{~cm})$ and Ficus sp. growth, probably owing to sapling die-back (Figure 3).

Table 2. Average sapling survival by species across three assessment intervals after the environmental restoration of a vereda (i.e., Mauritia flexuosa palm swamp) in southeastern Brazil. $\mathrm{N}=$ number of individuals, $\mathrm{SD}=$ standard deviation.

\begin{tabular}{|c|c|c|c|c|c|c|c|}
\hline \multirow{3}{*}{ Species } & \multirow{3}{*}{$\mathbf{N}$} & \multicolumn{6}{|c|}{ Sapling survival (\%) } \\
\hline & & \multicolumn{2}{|c|}{4 months } & \multicolumn{2}{|c|}{8 months } & \multicolumn{2}{|c|}{12 months } \\
\hline & & Mean & SD & Mean & SD & Mean & SD \\
\hline Calophyllum brasiliense Camb. & 27 & 35.19 & \pm 8.58 & 9.92 & \pm 2.73 & 8.80 & \pm 2.96 \\
\hline Calyptranthes brasiliensis Spreng. & 769 & 52.75 & \pm 7.75 & 22.61 & \pm 4.29 & 21.88 & \pm 3.84 \\
\hline Cecropia pachystachya Trécul & 191 & 82.16 & \pm 6.40 & 80.16 & \pm 6.59 & 77.04 & \pm 9.71 \\
\hline Croton urucurana Bailon & 15 & 93.33 & \pm 6.66 & 85.00 & \pm 9.57 & 85.00 & \pm 9.57 \\
\hline Erythroxylum citrifolium A.St-Hil. & 15 & 77.38 & \pm 15.03 & 75.00 & \pm 17.07 & 75.00 & \pm 17.07 \\
\hline Ficus sp. & 146 & 60.73 & \pm 12.64 & 50.37 & \pm 12.17 & 52.49 & \pm 12.46 \\
\hline Hirtella gracilipes (Hook.f.) Prance & 27 & 92.22 & \pm 5.71 & 84.29 & \pm 6.70 & 74.29 & \pm 10.93 \\
\hline Inga vera Willd & 337 & 51.90 & \pm 3.76 & 44.67 & \pm 4.59 & 42.79 & \pm 5.12 \\
\hline Ladenbergia cujabensis Klotzsch & 60 & 55.62 & \pm 9.79 & 45.27 & \pm 11.62 & 47.76 & \pm 11.65 \\
\hline Mauritia flexuosa L.f & 775 & 12.73 & \pm 3.90 & 9.23 & \pm 2.84 & 6.79 & \pm 2.96 \\
\hline Myrsine umbellata Mart & 389 & 58.29 & \pm 9.20 & 41.57 & \pm 10.87 & 38.77 & \pm 11.60 \\
\hline Nectandra megapotamica (Spreng.) Mez & 325 & 68.42 & \pm 8.85 & 61.60 & \pm 10.47 & 62.27 & \pm 9.57 \\
\hline Ocotea aciphyla (Nees\& Mart.) Mez & 44 & 64.38 & \pm 13.49 & 64.38 & \pm 13.49 & 57.24 & \pm 12.18 \\
\hline Piper aduncum L. & 203 & 41.86 & \pm 9.69 & 32.35 & \pm 9.57 & 14.33 & \pm 5.70 \\
\hline Tapirira guianenses Aubi & 414 & 77.16 & \pm 5.93 & 74.56 & \pm 6.73 & 70.11 & \pm 8.75 \\
\hline Total & 3.737 & 61.04 & \pm 2.78 & 51.10 & \pm 3.06 & 48.23 & \pm 3.15 \\
\hline
\end{tabular}




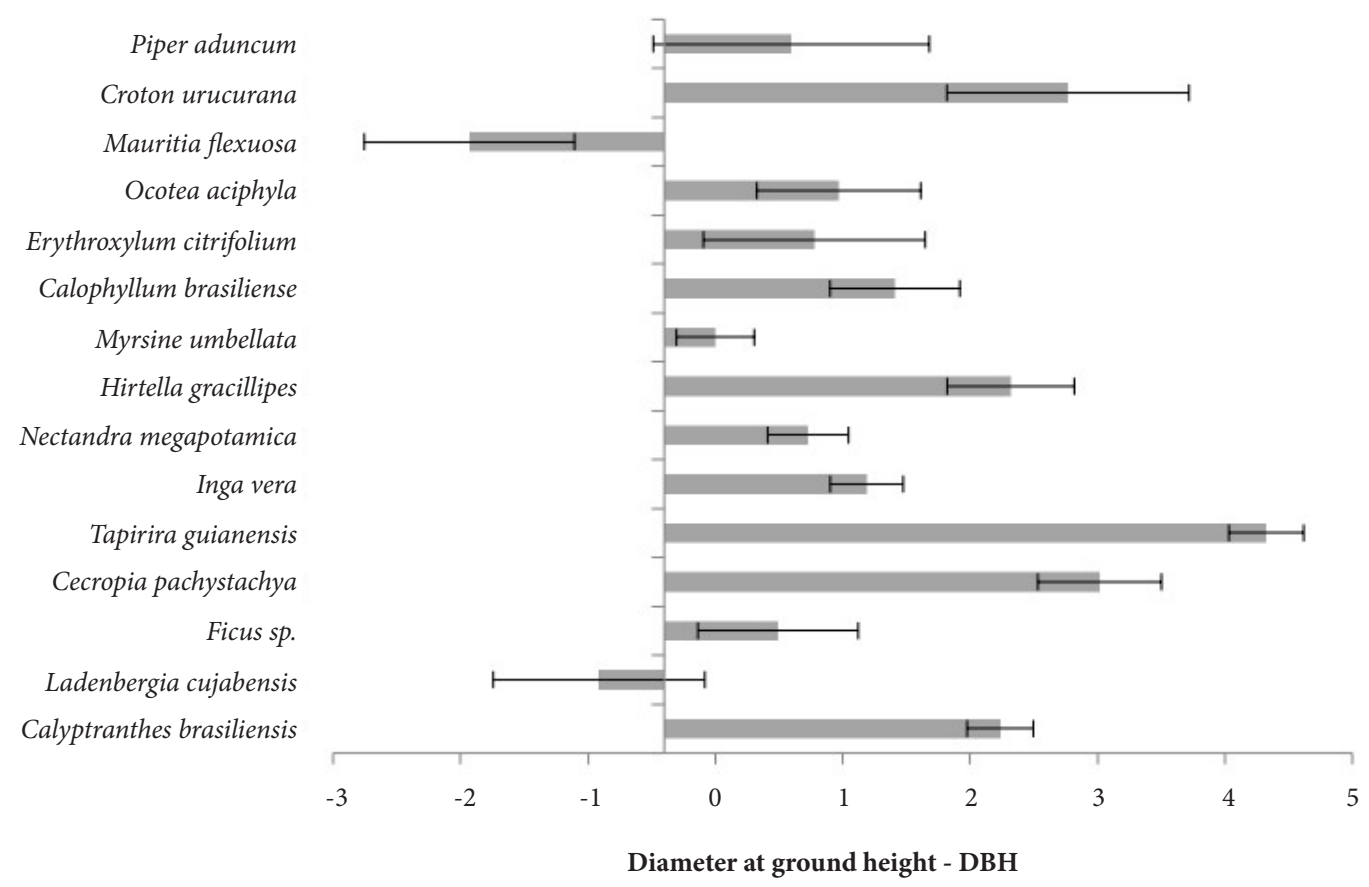

Figure 2. Average sapling growth in diameter at ground level $(\mathrm{mm})$ by species 12 months after the environmental restoration of a vereda (Mauritia flexuosa palm swamp) in southeastern Brazil.

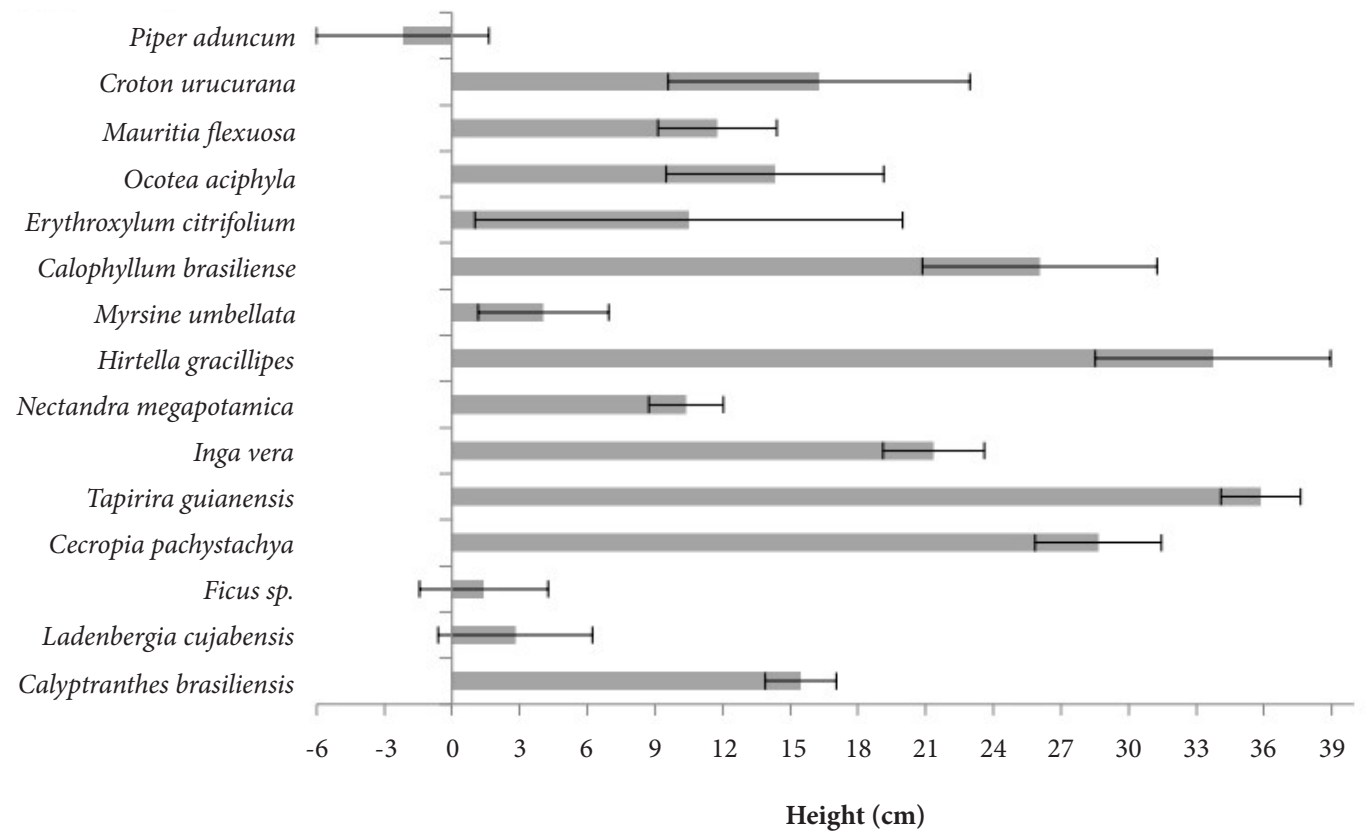

Figure 3. Average sapling growth in height (in $\mathrm{cm}$ ) by species 12 months after the environmental restoration of a vereda (Mauritia flexuosa palm swamp) in southeastern Brazil.

\section{DISCUSSION}

The success of a restoration project depends on several factors, mainly such as sapling survival and growth (Beltrame \& Rodrigues, 2008; Raman et al., 2009). In our study, total sapling survival varied across the study's timeframe and displayed a decreasing trend during the monitoring year, with higher sapling mortality after the first four months. High mortality at the initial phase of restoration projects is a common phenomenon (Raman et al., 2009; Fagundes, 2014). It largely owes to the stress caused by sapling transportation prior to and handling the during the planting process, and 
to the changes in environmental conditions faced by these plants, which are taken from the milder nursery conditions into the field. We found a similar percentage of total sapling survival (near 50\%) to that found in other studies (Lacerda \& Figueiredo, 2009; Fagundes, 2014; Marques et al., 2017), which is considered a satisfactory rate in Cerrado areas. Other studies which have considered higher thresholds of satisfactory survival rates have, unlike us, either employed fertilization and irrigation following sapling plantation, or have been conducted in moist or less degraded sites than ours. Among the species in our study, the considerable variation in survival and growth seem to denote their ecological characteristics and aptitude for vereda restoration (Mauritia flexuosa palm swamps).

The highest percentages of sapling survival and growth (both in diameter and height) are present by Cecropia pachystachya, Tapirira guianensis and Hirtella gracilipes. Erythroxylum citrifolium also featured among the species with highest survival, whereas Croton urucurana, among the species with highest survival and diameter growth. With the exception of H. gracilipes, all of these are pioneer, fast-growing and soil generalist species, occurring from floodplains to well-drained soils (Milhomem et al., 2013, Siqueira et al., 2016). The also soil generalist Nectandra megapotamica, which is an early secondary species, displayed high survival but low growth in our study. According to Raman et al. (2009), low-growth but high-survival species may be suitable for environmental restoration, since sapling survival is the main indicator of suitability for this purpose. Moreover, Marcuzzo et al. (2013) highlight the restoration potential of the highly plastic and fauna-attractive N. megapotamica, a species with high survival but low growth in our study. In field experiments, species behavior in face of adverse conditions at the restoration site directly influence their establishment and, consequently, restoration success (Fagundes, 2014). Therefore, differences among the species' ecological requirements directly influence their establishment success (Lebrija-Trejos et al. 2010). Lastly, some authors recommend that highly resistant species to environmental variation be used in environmental restoration projects.

Pioneers and early secondary species like $H$. gracilipes have faster establishment and high plasticity that may favor their survival under unfavorable conditions (Simmons et al. 2012). Other wetland restoration studies have found greater survival or growth for pioneer and early secondary species (Simmons et al., 2012; Fagundes, 2014), and have highlighted the importance of these ecological groups in creating favorable microenvironments for climax species and providing vertical structure for fauna in restoration projects. Pioneer and early secondary species, such as the abovementioned, may be suitable for the restoration of drained wetlands like our study site. Despite being typically found in wet environments (e.g., veredas, floodplains, wetlands in general), their ecological plasticity allows them to also withstand dry soil conditions. Therefore, these species' high sapling survival and growth indicate robustness and adaptability to the local conditions. Overall, this suggests that the species are good to recommend for restoration projects (Oliveira \& Joly, 2010; Fagundes, 2014) in disturbed and drained wetlands like our study site. This can be achieved with two steps: first, by planting pioneer and early secondary species, and then by enriching the area with late secondary species, once the area becomes able to support them.

In general, species of humid or water-saturated environments have shallow root systems (Nishimua et al., 2007) and struggle to establish on water-restricted soils. We observed this tendency with Calophyllum brasiliense, Calyptranthes brasiliensis, Ficus sp., Ladenbergia cujabensis, Mauritia flexuosa, Myrsine umbellata and Piper aduncum, all of which presented low survival and/or growth in our study. The former four are flood-tolerant, late secondary species that occur in water-saturated soils (Oliveira \& Joly, 2010; Gastauer et al., 2015). Other authors address the fact that soil humidity favors the establishment of these species, suggesting a preference for water-saturated or permanently waterlogged soils (Oliveira \& Joly, 2010; Fagundes, 2014). For instance, C. brasiliense displays high mortality under seasonal climates with well-defined and prolonged dry seasons (Calvo-Alvarado et al., 2007), which is the case in our study site. Lastly, Piper aduncum's decrease in height exemplifies a common phenomenon under water shortage: dieback caused by dryness of the aerial parts of a plant under soil drought conditions (Chakraborty et al., 2017).

On the other hand, M. flexuosa as a typical pioneer species of veredas and other wetlands (Resende et al. 2013; Fagundes \& Ferreira 2016). In fact, $M$. flexuosa's presence ultimately characterizes the veredas by promoting the maintenance of fauna and succession processes in these areas (Oliveira et al., 2009; Resende et al., 2012; Fagundes \& Ferreira, 2016). Mauritia. flexuosa's propagules and saplings display structural adaptations to persist in the swampy vereda environment (Silva et al., 2014). In a restoration experiment in another vereda, Fagundes (2014) recorded high survival averages in M. flexuosa and M. umbellata, with higher growth under permanent water saturation. Her results allow us to infer that the low survival attained by these species in our study site may be due to the water deficit promoted by the artificial drainage of the vereda.

The environmental conditions of a site prior to restoration efforts greatly influence the establishment of planted saplings. 
In most scenarios, water deficit is a stressful condition for plant establishment (Pozzobon et al., 2010), and even more so for species adapted to peat and wet vereda soils, like the secondary species planted in our study site (Bahia et al., 2009; Ávila et al., 2016). In addition to the water deficit promoted by the artificial drainage lines, the start of the experiment took place in an atypical year, when total precipitation was only a quarter of what would be expected, aggravating the soil water shortage (INMET, 2014). In the two months after planting, rainfall not occurs in study area, and occurs in little amount after that. Therefore, the low survival and growth rates presented by some of the species in our study may have owed to two sources of water deficit in our site: rainfall scarcity and anthropization (i.e., soil drainage).

On the other hand, some of the species, especially the pioneers, displayed high survival and growth on the drained soil at the initial moments of the experiment, which probably contributed to improve the site's conditions, and allow species with other ecological requirements to establish, therefore promoting restoration success. Despite the low precipitation received by the area in the study's timeframe, we have no reason to expect different results under normal precipitation conditions, because the artificial drainage lines promotes water deficit too. Veredas are strongly associated with hydromorphic or peat soils in headwater areas (Fagundes \& Ferreira, 2016), therefore very sensitive to water deficit. We recommend that the drainage lines be removed and that, if able to persist, the only natural drainage line be kept in the area. Drainage and anthropization of the study area compromise the resilience of this vereda, and studies like ours advance our understanding on how these environments can be successfully restored. Lastly, despite the importance of these ecosystems for the maintenance of ecosystem services in central and southeastern Brazil, we are not aware of similar studies conveying information about restoration of drained veredas.

\section{CONCLUSIONS}

The establishment of water-adapted species otherwise typically found in veredas was precluded by the water drainage conducted in our study site. In general, Croton urucurana, Cecropia pachystachya, Erythroxylum citrifolium, Hirtella gracilipes and Tapirira guianensis displayed the highest percentages of sapling survival and/or growth, mainly because of their generalist behavior that allows their establishment even on drained soils. However, other species attained less survival and growth percentages during the study period, likely because of the water shortage caused by soil drainage and low rainfall.

\section{ACKNOWLEDGEMENTS}

To Ministério Público de Minas Gerais - Coordenadoria Regional das Promotorias de Justiça do Meio Ambiente das Bacias dos Rios Verde Grande e Pardo, for the viability and support in the execution of the "Vereda Viva" project, to FAPEMIG through PPM 0623-16 of Maria das Dores M. Veloso; to CAPES for the PhD scholarship of Nathalle C. A. Fagundes. To Universidade Estadual de Montes Claros (Unimontes) and the students of Laboratório de Ecologia Vegetal for their assistance in the field work, and to RIMA Industrial S / A for logistical support and for giving up the area for the study.

\section{SUBMISSION STATUS}

Received: 28 May. 2020

Accepted: 4 October. 2020

Associate editor: Rodrigo Studart Corrêa (1)

\section{CORRESPONDENCE TO}

\section{Nathalle Cristine Alencar Fagundes}

Universidade do Estado de Minas Gerais, Ciências Biológicas, R. Ver. Geraldo Moisés da Silva, 308-434, CEP 38302-182, Ituiutaba, MG, Brasil. e-mail: nath_fag@yahoo.com.br

\section{REFERENCES}

Alvares CA, Stape JL, Sentelhas PC, Gonçalves, JLM, Sparovek G. Koppen's climate classification map for Brazil. Meteorologische Zeitschrift 2014; 22(6): 711-728.

Ávila MA, Souza SR, Veloso MDM, Santos RM, Fernandes LA, Nunes YRF. Structure of natural regeneration in relation to soil properties and disturbance in two swamp Forests. CERNE 2016; 22(1): 1-10.

Azevedo IFP, Nunes YRF, Ávila MA, Silva DL, Fernandes GW, Veloso $\mathrm{RB}$. Phenology of riparian tree species in a transitional region in southeastern Brazil. Revista Brasileira de Botânica2014; 37(1): 47-59.

Azevedo IFP, Nunes YRF, Veloso MDM, Neves WV, Fernandes GW. Preservação estratégica para recuperar o São Francisco. Scientific American Brasil 2009; 83: 74-79.

Bahia TO, Luz GR, Veloso MDM, Nunes YRF, Neves WV, Braga LL, Lima PCV. As veredas da APA do Rio Pandeiros: importância, impactos ambientais e perspectivas.MG Biota 2009; 2(2): 4-13.

Calvo-Alvarado JC, Arias D, Richter DD. Early growth performance of native and introduced fast growing tree species in wet to subhumid climates of the southern region of Costa Rica. Forest Ecology and Management 2007; 242: 227-235.

Caspersen JP, Kobe KR. Interspecific variation in sapling mortality in relation to growth and soil moisture Copenhage. Oikos 2001;92(1): 160-168.

Chakraborty T, Saha S, Matzarakis A. Influence of multiple biotic and abiotic factors on the crown die-back of European beech trees at their drought limit. Flora 2017; 229: 58-70. 
Fagundes NCA. Estabelecimento de mudas implantadas na restauração de um trecho de floresta higrófila na vereda do Acari, Chapada Gaúcha, MG, Brasil.[Dissertação]. Montes Claros: Departamento de Biologia Geral, Universidade Estadual de Montes Claros; 2014.

Fagundes NCA, Ferreira EJ. Veredas (Mauritia Flexuosa palm swamps) in the southeast Brazilian savanna: Floristic and structural peculiarities and conservation status. Neotropical Biology and Conservation 2016; 11(3):178-183.

Gastauer M, Sobral MEG, Meira-Neto JAA. Preservation of primary forest characteristics despite fragmentation and isolation in a forest remnant from Viçosa, MG, Brazil. Revista Árvore 2015; 39(6): 985-994.

INMET - Instituto Nacional de Meteorologia 2014. Acessado em junho 2016. Disponível em: http//www.inmet.com.br.

Kurtz, BC, Gomes, JC, Scarano, FR. Structure and phytogeographic relationships of swamp forests of Southeast Brazil. Acta Botanica Brasilica 2013; 27:647-660.

Lacerda DMA, Figueiredo PS. Restauração de matas ciliares do rio Mearim no município de Barra do Corda MA: Seleção de espécies e comparação de metodologias de reflorestamento. Acta Amazonica 2009, 39(2): 295-304.

Lebrija-Trejos D, Pérez-García EA, Meave JA, Bongers F, Poorter L. Functional traits and environmental filtering drive community assembly in a species-rich tropical system. Ecology 2010; 91(2): 386-398

Maillard P, Pereira DB, Souza CG. Incêndios florestais em Veredas: Conceitos e estudo de caso no Peruaçu. Revista Brasileira de Cartografia 2009; 61(4): 321-330.

Marcuzzo SB, Araújo MM, Longhi SJ. Estrutura e relações ambientais de grupos florísticos em fragmento de floresta estacional subtropical. Revista Árvore 2013; 37(2), 275-287.

Marques IC, Pereira IM, Silva MAP, Oliveira MLR, Titon M. Desenvolvimentoinicialdequatro espécies nativas do Cerrado sob diferentes dosagens de composto orgânico, em uma cascalheira, em Diamantina, Minas Gerais. Agrarian Academy 2017; 4(7): 137-151.

Maruyama PK, Borges MR, Silva PA, Burns KC, Melo, C. Avian frugivory in Miconia (Melastomataceae): contrasting fruiting times promote habitat complementarity between savanna and palm swamp. Journal of Tropical Ecology 2013; 29: 99-109.

Milhomem MEV, Araújo GM, Vale VS. Estrutura do estrato arbóreo e regenerativo de um fragmento de floresta estacional semidecidual em itumbiara, GO. Ciência Florestal 2013; 23(4): 679-690.

Moreira SN, Eisenlohr PV, Pott A, Pott VJ, Oliveira Filho AT. Similar vegetation structure in protected and non-protected wetlands in Central Brazil: conservation significance. Environmental Conservation 2015;42:356-362.

Neri AV, Soares MP, Meira-Neto JAA, Dias LE. Espécies de Cerrado com potencial para recuperação de áreas degradadas por mineração de ouro, Paracatu-MG. Revista Árvore 2011; 35(4): 907-918.

Nishimua TB, Suzuki E, Kohyama T, Tsuyuzaki S. Mortality and Growth of Trees in Peat-Swamp and Heath Forests in Central Kalimantan after Severe Drought. Plant Ecology 2007;188(2):165-177.

Nunes YRF, Mendonça AVR, Botezelli L, Machado ELM, OliveiraFilho, AT. Variações da fisionomia, diversidade e composição de guildas da comunidade arbórea em um fragmento de floresta semidecidual em Lavras, MG. Acta botanica brasilica 2003; 17(2): 213-229.

Oliveira GC, Araújo GM, Barbosa AAA. Florística e zonação de espécies vegetais em veredas no triângulo mineiro, Brasil. Rodriguésia 2009; 60(4): 1077-1083.

Oliveira VC, Joly CA. Flooding tolerance of Calophyllum brasiliense Camb. (Clusiaceae): morphological, physiological and growth responses. Trees 2010; 24(1): 185-193.

Pennington RT, Lavin M, Oliveira-Filho AT. Woody Plant Diversity, Evolution, and Ecology in the Tropics: Perspectives from Seasonally Dry Tropical Forests. Rev. Ecol. Evol 2009; 40: 437-457.

Pereira JS, Rodrigues SC. Crescimento de espécies arbóreas utilizadas na recuperação de área degradada. Caminhos de Geografia Uberlândia 2012; 13(41): 102-110.

Pozzobon M, Curcio GR, Uhlmann A, Galvão F, Zimmer E. Restauração de planícies do rio Itajaí-Açu SC: Sobrevivência e crescimento inicial de espécies arbóreas nativas por tipos de solo. Pesquisa Florestal Brasileira 2010; 30(63): 171-189.

Raman TRS, Mudappa D, Kapoor V. Restoring Rainforest Fragments: Survival of Mixed-Native Species Seedlings under Contrasting Site Conditions in the Western Ghats, Índia. Restoration Ecology 2009; 17(1): 137-147.

Resende ILM, Chaves LJ, Rizzo JA. Floristic and phytosociological analysis of palm swamps in the central part of the Brazilian savana. Acta Botanica Brasilica 2013; 27(1): 205-225.

Resende ILM, Santos FP, Chaves LJ, Nascimento JL. Estrutura etária de populações de Mauritia flexuosa L. F. (Arecaceae) de veredas da Região Central de Goiás, Brasil. Revista Árvore 2012; 36: 103-112.

Ressel K, Guilherme FAG, Schiavini I, Oliveira PE. Ecologia morfofuncional de plântulas de espécies arbóreas da Estação Ecológica do Panga, Uberlândia, Minas Gerais. Revista Brasileira Botânica 2004; 27(2): 311-323.

Rizzini CT. Tratado de Fitogeografia do Brasil: aspectos ecológicos, sociológicos e florísticos. 2 ed. Rio de Janeiro: Âmbito cultural; 1997.

Sabonaro DZ, Santos V, Russo LRM, Oliveira AP, Simonetti VC. Plantio de mudas com adubações distintas nas margens do córrego, em Alumínio - SP. Revista da Universidade Vale do Rio Verde 2015; 13(2): 265-274.

Silva CT, Reis GG, Reis MGF, Silva E, Chaves RA. Avaliação temporal da florística arbórea de uma floresta secundária no município de Viçosa, Minas Gerais. Revista Árvore 2004; 28: 429-441.

Silva RS, Ribeiro LM, Mercadante-Simões MO, Nunes YRF, Lopez PSN. Seed structure and germination in buriti (Mauritia flexuosa), the swamp palm. Flora 2014; 209: 674-685.

Simmons ME, Wu XB, Whisenante SG. Responses of pioneer and later-sucessional plant assemblages to created microtopographic variation and soil treatments in riparian forest restoration. Restoration Ecology 2012; 20:369-377.

Siqueira KN, Ferreira HD, Tostano TG, Santos JH, Silva MG. Quais espécies de árvores estão na borda da floresta estacional do cerrado? Revista Tree dimensional, Pro Floresta 2016; 1(1): 11.

Zar JH. Biostatisticalanalysis. Prentice-Hall, Englewood Cliffs, New Jersey. 1996. 